\title{
The "selfish brain" hypothesis for metabolic abnormalities in bipolar disorder and schizophrenia
}

\author{
A hipótese do "cérebro egoísta" para alterações metabólicas \\ no transtorno bipolar e na esquizofrenia
}

Rodrigo Barbachan Mansur, ${ }^{1}$ Elisa Brietzke ${ }^{2}$

\begin{abstract}
Metabolic abnormalities are frequent in patients with schizophrenia and bipolar disorder (BD), leading to a high prevalence of diabetes and metabolic syndrome in this population. Moreover, mortality rates among patients are higher than in the general population, especially due to cardiovascular diseases. Several neurobiological systems involved in energy metabolism have been shown to be altered in both illnesses; however, the cause of metabolic abnormalities and how they relate to schizophrenia and BD pathophysiology are still largely unknown. The "selfish brain" theory is a recent paradigm postulating that, in order to maintain its own energy supply stable, the brain modulates energy metabolism in the periphery by regulation of both allocation and intake of nutrients. We hypothesize that the metabolic alterations observed in these disorders are a result of an inefficient regulation of the brain energy supply and its compensatory mechanisms. The selfish brain theory can also expand our understanding of stress adaptation and neuroprogression in schizophrenia and $\mathrm{BD}$, and, overall, can have important clinical implications for both illnesses.
\end{abstract}

Keywords: Schizophrenia, bipolar disorder, metabolism, brain metabolism, stress, allostasis.

\begin{abstract}
Resumo
Alterações metabólicas são frequentes em pacientes com esquizofrenia e transtorno bipolar (TB), levando a uma alta prevalência de diabetes e síndrome metabólica nessa população. Além disso, as taxas de mortalidade entre pacientes são mais altas do que na população geral, especialmente em decorrência de doenças cardiovasculares. Vários sistemas neurobiológicos envolvidos no metabolismo energético têm demonstrado alterações nas duas doenças; no entanto, a causa das alterações metabólicas e a forma como elas se relacionam com a fisiopatologia da esquizofrenia e do TB ainda são arenas em grande parte desconhecidas. A teoria do "cérebro egoísta" é um paradigma recente que postula que, para manter estável seu próprio fornecimento de energia, o cérebro modula o metabolismo da energia na periferia regulando tanto a alocação quanto a ingestão de nutrientes. Apresentamos neste artigo a hipótese de que as alterações metabólicas observadas nesses transtornos são resultado de uma regulação ineficiente do fornecimento de energia do cérebro e seus mecanismos compensatórios. A teoria do cérebro egoísta também pode expandir nosso entendimento sobre a adaptação ao estresse e a neuroprogressão na esquizofrenia e no TB, e, acima de tudo, pode ter implicações clínicas importantes para as duas doenças.
\end{abstract}

Descritores: Esquizofrenia, transtorno bipolar, metabolismo, metabolismo cerebral, estresse, alostase.

\footnotetext{
${ }^{1}$ MD. Program for Recognition and Intervention in Individuals in at Risk Mental State, Department of Psychiatry, Universidade Federal de São Paulo (UNIFESP), São Paulo, SP, Brazil. Interdisciplinary Laboratory of Clinical Neurosciences (LINC), Department of Psychiatry, UNIFESP. ${ }^{2}$ MD, PhD. Program for Recognition and Intervention in Individuals in at Risk Mental State, Department of Psychiatry, UNIFESP. Interdisciplinary Laboratory of Clinical Neurosciences (LINC), Department of Psychiatry, UNIFESP.

Submitted May 21 2012, accepted for publication Jun 13 2012. No conflicts of interest declared concerning the publication of this article.

Suggested citation: Mansur RB, Brietzke E. The "selfish brain" hypothesis for metabolic abnormalities in bipolar disorder and schizophrenia. Trends Psychiatry Psychother. 2012;34(3):121-8.
} 


\section{Introduction}

Schizophrenia and bipolar disorder (BD) are frequent and potentially severe psychiatric disorders, which affect, together, $3 \%$ of the population. ${ }^{1,2}$ These illnesses typically start in adolescence or early adulthood and usually develop a chronic and debilitating course. According to the World Health Organization, both are among the 10 major causes of disability. ${ }^{3}$ Despite progresses in treatment, medications are still limited in their clinical efficacy, and few individuals recover their previous level of functioning. ${ }^{4,5}$ Moreover, schizophrenia and BD are associated with a wide range of medical comorbidities, ${ }^{6,7}$ with higher mortality rates than expected. ${ }^{8,9}$

Although schizophrenia and BD are distinct conditions, recent findings from several lines of evidence converge to the idea that they share several pathophysiological processes. There is a genetic susceptibility common to both of them, including the identification of genes, such as DISC1, dysbindin, NRG1-A, and DAO. ${ }^{10}$ Structural neuroimaging studies have also found similarities in the pattern of changes induced by the two diseases. For example, an increase of the lateral ventricles and a reduction in hippocampal volume have been found in both conditions, however more markedly in patients with schizophrenia than in those with BD. ${ }^{11}$ These volumetric deviations may be related to imbalances in factors regulating neuronal and glial survival. Reductions in neurotrophins, such as brain-derived neurotrophic factor (BDNF), have been repeatedly demonstrated in schizophrenia ${ }^{12}$ and $B D$ both during mood episodes and in periods of euthymia. ${ }^{13}$ Similarly, altered peripheral levels of mediators involved in the regulation of neuroplasticity, such as factors of apoptosis and inflammation markers, have been documented in schizophrenia ${ }^{14,15}$ and in BD. ${ }^{16-18}$

Recently, several authors have proposed that schizophrenia and BD are progressive in nature, with substantial differences between early and late stages in terms of clinical presentation, treatment response, and neurobiological characteristics. ${ }^{19,20}$ Shorter interepisodic intervals, worse cognitive functioning, increased risk of suicide, and a worse response to pharmacotherapy and psychotherapy are related with a greater number of episodes of BD. ${ }^{21}$ Late stages of these diseases are also associated with more pronounced brain morphology alterations, as well as other neurobiological abnormalities such as low levels of BDNF and increased levels of inflammatory cytokines and oxidative stress markers. ${ }^{22,23}$ However, despite the robust evidence pointing to the progressive nature of schizophrenia and $\mathrm{BD}$, the neurobiological substrates of this progression are not well known.

\section{Metabolic abnormalities in schizophrenia and BD}

The increased mortality observed in patients with schizophrenia and $\mathrm{BD}$, along with an increased incidence of cardiovascular disease and diabetes, ${ }^{24-26}$ has motivated the investigation of metabolic alterations. In fact, the prevalence of obesity and metabolic syndrome is substantially higher in these patients than in the general population. ${ }^{27,28}$ Factors such as the use of medication, especially atypical antipsychotics, dietary habits, and lifestyle seem to exert an influence on this higher prevalence. However, studies involving firstepisode patients without previous use of medication have shown metabolic abnormalities to be present even before treatment. ${ }^{29-31}$ While a sedentary lifestyle and a poor diet are important factors, they alone are not able to explain all the differences observed. ${ }^{32}$ Results indicate that metabolic dysfunction is a component of the pathophysiology of disease from its onset. In addition, diabetes and metabolic syndrome are associated with brain changes similar to those of mental illness. ${ }^{33}$ Atrophy of structures such as the hippocampus and the amygdala have been reported, ${ }^{34,35}$ as well as cognitive deficits (e.g. worse performance on attention tasks, working memory, and executive function) that are indicative of brain dysfunction. ${ }^{36}$

\section{Physiology of brain energy metabolism}

The central nervous system (CNS) has some particularities in relation to energy metabolism. Brain tissue consumes high levels of energy; although the brain accounts for only $2 \%$ of the total body mass, it spends approximately $25 \%$ of the glucose available in the body. Neuronal activity and the release of neurotransmitters and neuropeptides require large amounts of energy. ${ }^{37}$ Despite this high demand, the CNS has a low storage capacity, with low levels of glycogen or lipids. Furthermore, brain tissue is almost entirely dependent on glucose metabolism, while peripheral tissues are able to use carbohydrates, proteins and fats. These characteristics make the maintenance of a steady supply of glucose crucial for a normal brain operation. The blood-brain barrier plays an important role in this regulation, since various substrates and hormones are actively transported by specific mechanisms. ${ }^{38}$

\section{The "selfish brain" theory}

Due to the special position of the CNS relative to energy metabolism, several authors have stated that this system actively regulates the production and distribution of energy throughout the body, with emphasis on 
regulating its own adenosine triphosphate (ATP) concentration. ${ }^{39}$ This idea is supported by observations that, in situations of severe malnutrition, all organs, including the heart, lungs, and kidneys, show a decrease of up to $40 \%$ in weight, while brain tissue mass remains unchanged. ${ }^{40}$ Thus, some authors have developed the "selfish brain" theory, ${ }^{39}$ according to which the brain would prioritize its own availability of glucose.

The availability of energy to neurons is determined by the concentration of ATP. When ATP concentration decreases, an ATP-dependent potassium channel is opened, allowing the flow of potassium to the extracellular space, hyperpolarizing the neuron and making it refractory. Because there are differences in channel affinity between excitatory (glutamatergic - high affinity for ATP) and inhibitory (GABA - low affinity for ATP) neurons, low but non-critical levels of ATP reduce the activity of inhibitory neurons only, keeping excitatory ones active and thus leading to an increased release of glutamate in the system, with both local and systemic effects. Locally, glutamate release promotes glucose uptake by astrocytes through the blood-brain barrier, in order to balance the availability of ATP. Systemically, there is activation of the hypothalamic-pituitary-adrenal (HPA) axis and of the sympathetic nervous system (SNS), which together inhibit the absorption of glucose in the periphery, increasing its availability to the CNS and promoting an increase in appetite and food intake. ${ }^{39}$

This theory was tested by Hitze et al. ${ }^{41}$ who exposed individuals to a stressful situation and subsequently to a buffet with different types of food. Blood samples were collected throughout the study. Previous studies have shown that acute mental stress increases brain energy consumption by $12 \% .{ }^{42}$ In the study by Hitze et al. ${ }^{41}$ exposure to stress increased the intake of carbohydrates, but not of fat and protein. Carbohydrate consumption, as expected, increased blood glucose, however with no subsequent increase in insulin among stressed individuals. Those findings suggest that stress response, through HPA axis activation, inhibited insulin secretion via the pancreas. As glucose uptake in the CNS is insulinindependent, the suppression of the latter increases the amount of glucose available to the brain. This supports the concept that the brain modulates energy metabolism in the periphery in order to ensure an adequate energy supply and maintain normal functioning under different circumstances.

\section{Metabolic systems involved in the patho- physiology of psychiatric disorders}

Several neurobiological abnormalities related to energy metabolism, both centrally and peripherally, have been described in schizophrenia and BD. Astrocytes are glial cells responsible for glucose uptake from capillary vessels and, through the conversion and release of lactate, for the delivery of energetic substrate for neurons. Therefore, abnormalities in astrocytes may directly impact brain energy metabolism. Interestingly, astrocyte and glial cell pathology has been repeatedly shown in schizophrenia and $B D$, both in post-mortem and in neuroimaging studies. ${ }^{43,44}$ Moreover, the S100B protein can be found in glial cells, especially astrocytes, and has been considered as a marker of astrocyte integrity. Increased levels of this protein were found in schizophrenia, particularly in unmedicated patients, ${ }^{45,46}$ and also in BD patients, mainly during manic or depressive episodes. ${ }^{45,47}$

Because brain tissues use glucose metabolism as their energetic substrate, they are highly dependent on mitochondrial function. Any mitochondrial abnormality will greatly impact the brain. In patients with schizophrenia or BD, changes in the morphology and number of mitochondria have been detected in brain tissue, ${ }^{48,49}$ as well as a down-regulation of mitochondriarelated genes. ${ }^{50}$ Mitochondrial function, which involves ATP production, reactive oxygen species homeostasis, and apoptosis regulation, is also altered. ${ }^{51,52}$ Medications used in the treatment of these disorders have an influence on mitochondria, with mood stabilizers (e.g., lithium and valproate) reverting some of these abnormalities, which could explain the beneficial effects of these agents. ${ }^{53,54}$ Curiously, antipsychotics may have the opposite effect and impair mitochondrial function. ${ }^{55,56}$

Peripherally, metabolic abnormalities are also observed. In addition to the higher prevalence of diabetes and insulin resistance mentioned above, first-episode, drug-naive patients already display increased levels of glucose and insulin, as well as insulin resistance rates. ${ }^{30,57,58}$ Insulinrelated peptides, such as proinsulin and peptide $\mathrm{C}$, were also shown to be increased in this population, regardless of glucose levels. ${ }^{59}$ Alterations in the plasma levels of lipids are another common metabolic alteration of schizophrenia and BD. Triglyceri des and lipoproteins, such as low-density and high-density lipoproteins (LDL and HDL), have shown abnormal levels in chronic ${ }^{60,61}$ and first-episode, drugnaive patients. ${ }^{62}$ Among fatty acids, the omega-3 group has been the focus of increasing attention, as a result of epidemiological studies linking high rates of dietary omega-3 with low levels of cardiovascular disease, diabetes, and depression. ${ }^{63}$ In fact, different levels of omega- 3 have been reported in patients with schizophrenia and BD. ${ }^{64,65}$ Interestingly, omega-3 fatty acids also have an important role in brain energy metabolism, exerting an influence on brain glucose uptake. ${ }^{66}$

The stress response system plays an important role in brain energy metabolism by increasing the availability of 
energetic substrates and directing it to the CNS. It is also one of the most robust and most frequently replicated neurobiological abnormalities in schizophrenia and BD. Patients with schizophrenia present long periods of increased cortisol secretion, especially those experiencing their first episode and not previously treated. ${ }^{67}$ They also show low reactivity to stress, with a blunted cortisol response to psychosocial stress. ${ }^{67}$ In BD, studies have shown altered corticotropin-releasing hormone $(\mathrm{CRH})$ secretion previous to symptom onset, ${ }^{68}$ cortisol hypersecretion in euthymia, depression and mania, ${ }^{69}$ and a non-normalization of the HPA axis after symptom remission. ${ }^{70}$ Overall, evidence points to disturbances of the stress response system as a trait of both illnesses.

Another point of intersection between energy metabolism and psychiatric disorders is the BDNF. This protein is considered an important neuroplasticity marker and is involved in several processes, such as neuronal differentiation and synaptic plasticity. ${ }^{71}$ Altered BDNF levels and genetic expression are well documented in schizophrenia ${ }^{12}$ and $\mathrm{BD}, 72,73$ and are associated with episodes as well as with length of illness. ${ }^{12,13,73}$ Interestingly, BDNF has also been implicated in energy metabolism. ${ }^{74}$ The Val66Met polymorphism of the BDNF gene is associated with a higher body mass index (BMI) in healthy individuals. ${ }^{75}$ In the hypothalamus, BDNF expression was shown to be inhibited by dietary restriction and enhanced by energy availability, especially glucose. ${ }^{76,77}$ Moreover, diminished BDNF expression produced hyperphagia and obesity in an animal model. 77,78

Could all these metabolic abnormalities described in schizophrenia and BD be better explained by adopting a single and comprehensive paradigm? The selfish brain theory provides a cohesive conceptual framework for answering that question. We hypothesize that central and peripheral metabolic alterations are related to an inefficient regulation of brain energy homeostasis. A higher energetic demand, due to chronic exposure to stress, or a deregulation of cellular and hormonal metabolic processes could cause a deficit in brain energy supply, disrupting normal brain function and manifesting as psychopathology. Moreover, the adaptive mechanisms triggered by the effort of normalizing brain energy supply, such as HPA axis activation and food intake stimulation, might be the basis of the peripheral alterations often observed in the patients and that frequently develop into diabetes, metabolic syndrome, and cardiovascular disease.

\section{Brain energy metabolism and stress adap- tation}

Stress represents a challenge to the system. In order to deal with this challenge, the mobilization of energetic resources is necessary. As discussed above, stressful experiences can increase the brain metabolic activity by $12 \% .42$ In fact, even cognitive work, as in computer-based activities or video game playing, appears to increase brain demand and consequently food intake. ${ }^{79}$ Hypoglycemic states are known to induce neuroglycopenic symptoms, such as hunger, dizziness, and difficulty thinking. ${ }^{80}$ Stressed individuals, however, show these neuroglycopenic symptoms even at normal blood glucose level, corresponding to a state of energetic deficit in the brain. ${ }^{41}$ Interestingly, individuals have also been reported to develop mood symptoms after a stressful experience, and these were, as were neuroglycopenic symptoms, reversed after energy supplementation. ${ }^{41}$ Energy deficit disrupts normal brain functions; therefore, brain homeostasis is directly linked to the system's capacity of achieving energetic balance.

Adaptation to stress is now recognized as an important factor in the pathophysiology of both schizophrenia and BD. ${ }^{81}$ In addition, stressful events are common triggers of psychotic and mood episodes. ${ }^{82,83}$ Several known risk factors for both illnesses, such as early life adversities, childhood maltreatment, urbanicity, and drug abuse, directly impact and modulate stress response systems, and the risk of developing schizophrenia or BD is known to increase with a cumulative exposure to stressful life events. ${ }^{84}$ The impact of stress seems to be stronger in the period preceding the onset of the first episode, ${ }^{85-87}$ although it is also associated with symptom severity and chronicity. ${ }^{88}$ Moreover, patients exhibit a higher sensitivity to daily life stress, which has important clinical implications. ${ }^{89}$

Despite the irrefutable evidence of the major role of stress in schizophrenia and BD, it remains unclear how and through which mechanisms this pathophysiological process occurs. The relationship between stress and psychopathology is not merely linear. Health is not just a static point of equilibrium; it also involves the capacity to adapt to the environment and meet external and internal demands. ${ }^{90}$ Allostasis is a more recent model of regulation and is focused on anticipatory responses to predicted demands. ${ }^{90,91}$ This model highlights the importance of brain control over regulatory processes, allowing stability points to fluctuate according to environmental demands. ${ }^{90,91}$ Allostasis also involves an intricate and orchestrated network of mediators ${ }^{92}$ that enhance regulation efficiency through broad and complementary responses. ${ }^{90}$ For example, hypoglycemia stimulates the secretion of several hormones, such as glucagon and growth hormone, activates the autonomic nervous system, and, most importantly, provokes the sensation of hunger and motivates food seeking behavior. The allostasis model provides a better and more 
comprehensive paradigm for the study of stress in the pathophysiology of schizophrenia and BD. Brain energy metabolism regulation, as described by the selfish brain theory, is intrinsically related to stress adaptation and can serve as a new theoretical framework integrating stress response abnormalities and the metabolic alterations observed in patients with schizophrenia and BD.

\section{Clinical implications of brain energy me- tabolism dysfunction}

Schizophrenia and BD are progressive disorders. ${ }^{19,20}$ Several clinical features, such as severity and persistence of symptoms, cognitive and functional impairment, suicide risk, as well as treatment response, are clearly associated with length of illness and/or number of episodes. ${ }^{93}$ Clinical progression is accompanied by neuroprogression, as shown by evidence pertaining to biomarkers and neuroanatomical differences between early and late illness stages. ${ }^{22}$ Putatively, neuroprogression is caused by the accumulation of stress exposure and its adaptive responses over time, a process that is called allostatic load. ${ }^{94}$ Several biomarkers have been proposed as mediators of allostatic load, e.g., inflammatory and oxidative stress markers. ${ }^{94}$ Regulatory mechanisms of brain energy play a major role in adaptive and allostatic processes. Dysfunction of these mechanisms may be a contributing factor to neuroprogression in schizophrenia and BD.

Cognitive impairment is a core feature of schizophrenia and $\mathrm{BD}$, being highly prevalent and one of the most important causes of disability. ${ }^{95,96}$ It is also one of the consequences of the progressive nature of these illnesses. ${ }^{93}$ As seen above, cognitive work is energetically demanding ${ }^{79}$; consequentially, based on our hypothesis, it can be disturbed by an inefficient regulation of brain energy. This highlights the importance of taking metabolic issues into account in studies focusing on cognition. Moreover, interventions focused on brain energy dysfunction, such as pharmacological approaches or dietary and lifestyle changes, may be beneficial for cognitive function.

Finally, another clinical implication of recognizing brain energy dysfunction as a component of the pathophysiology of schizophrenia and $\mathrm{BD}$ is related to prevention. From the concept of neuroprogression arises the idea that early intervention may prevent a deteriorative course of illness. ${ }^{23}$ In fact, there is currently a major ongoing effort in psychiatric research to optimize early recognition and diagnosis of schizophrenia and $\mathrm{BD}$, including the identification of prodromal states. ${ }^{97,98}$ Studies focusing on pre-clinical stages, the so-called "atrisk mental states," are successfully developing criteria to reliably identify those individuals. ${ }^{97}$ Intervention studies have also been conducted in an attempt to prevent the development of a full-blown, clinical illness. ${ }^{99}$ However, due to the complex and dynamic nature of schizophrenia and $\mathrm{BD}$, identification criteria are not totally accurate and tend to have a high rate of false positive results. ${ }^{97}$ This raises a major concern on the use of psychotropic medications in this population. ${ }^{100}$ Rather, interventions focused on brain energy regulation may be capable of a disease-modifier effect, without the risk and side effects associated with medications.

\section{Conclusion}

Metabolic abnormalities are common in schizophrenia and $\mathrm{BD}$, involving a plethora of neurobiological systems related to energy regulation. The selfish brain theory postulates that the CNS modulates energy metabolism in the periphery in order to prioritize its own demand, ${ }^{39}$ providing a unified conceptual framework for the understanding of these phenomena. Brain energy regulation is also a crucial component of stress adaptation, in both short and long terms. An inefficient regulation can be associated with pathological processes in the body and in the brain. Therefore, a better understating of how this regulation takes place in schizophrenia and BD patients could help elucidate several features of these illnesses and provide a platform for further studies of pathophysiology and intervention.

\section{References}

1. Kessler RC, Berglund $P$, Demler $O$, Jin R, Merikangas $K R$, Walters EE. Lifetime prevalence and age-of-onset distributions of DSM-IV disorders in the National Comorbidity Survey Replication. Arch Gen Psychiatry. 2005;62:593-602.

2. Perala J, Suvisaari J, Saarni SI, Kuoppasalmi K, Isometsa E, Pirkola S, et al. Lifetime prevalence of psychotic and bipolar I disorders in a general population. Arch Gen Psychiatry. 2007;64:19-28.

3. Mathers CD, Lopez AD, Murray CJL. The burden of disease and mortality by condition: data, methods, and results for 2001. In: Lopez A, Mathers C, Ezzati M, Jamison DT, Murray $\mathrm{CJL}$, editors. Global burden of disease and risk factors. Washington: The World Bank and Oxford University Press; 2006. p. 45-240.

4. Tohen M, Hennen J, Zarate CM Jr., Baldessarini RJ, Strakowski $S M$, Stoll AL, et al. Two-year syndromal and functional recovery in 219 cases of first-episode major affective disorder with psychotic features. Am J Psychiatry. 2000;157:220-8.

5. Swartz MS, Perkins DO, Stroup TS, Davis SM, Capuano G, Rosenheck RA, et al. Effects of antipsychotic medications on psychosocial functioning in patients with chronic schizophrenia: findings from the NIMH CATIE study. Am J Psychiatry. 2007;164:428-36. 
6. Perron BE, Howard MO, Nienhuis JK, Bauer MS, Woodward AT, Kilbourne AM. Prevalence and burden of general medical conditions among adults with bipolar I disorder: results from the National Epidemiologic Survey on Alcohol and Related Conditions. J Clin Psychiatry. 2009;70:1407-15.

7. Weber NS, Cowan DN, Millikan AM, Niebuhr DW. Psychiatric and general medical conditions comorbid with schizophrenia in the National Hospital Discharge Survey. Psychiatr Serv. 2009;60:1059-67.

8. Angst F, Stassen HH, Clayton PJ, Angst J. Mortality of patients with mood disorders: follow-up over 34-38 years. J Affect Disord. 2002;68:167-81.

9. Saha S, Chant D, McGrath J. A systematic review of mortality in schizophrenia: is the differential mortality gap worsening over time? Arch Gen Psychiatry. 2007;64:1123-31.

10. Ivleva E, Thaker G, Tamminga CA. Comparing genes and phenomenology in the major psychoses: schizophrenia and bipolar 1 disorder. Schizophr Bull. 2008;34:734-42.

11. McDonald C, Marshall N, Sham PC, Bullmore ET, Schulze K, Chapple B, et al. Regional brain morphometry in patients with schizophrenia or bipolar disorder and their unaffected relatives. Am J Psychiatry. 2006;163:478-87.

12. Green MJ, Matheson SL, Shepherd A, Weickert CS, Carr VJ. Brain-derived neurotrophic factor levels in schizophrenia: a systematic review with meta-analysis. Mol Psychiatry. 2011;16:960-72.

13. Cunha $A B$, Frey $B N$, Andreazza $A C$, Goi JD, Rosa $A R$, Goncalves CA, et al. Serum brain-derived neurotrophic factor is decreased in bipolar disorder during depressive and manic episodes. Neurosci Lett. 2006;398:215-9.

14. Smesny S, Kunstmann C, Kunstmann S, Willhardt I, Lasch J, Yotter RA, et al. Phospholipase A(2) activity in first episode schizophrenia: associations with symptom severity and outcome at week 12. World J Biol Psychiatry. 2011;12:598-607.

15. Mansur RB, Zugman A, Asevedo E, da Cunha GR, Bressan RA. Cytokines and schizophrenia: possible role of antiinflammatory medications in clinical and pre-clinical stages. Psychiatry Clin Neurosci. 2012. In press.

16. Schloesser RJ, Huang J, Klein PS, Manji HK. Cellular plasticity cascades in the pathophysiology and treatment of bipolar disorder. Neuropsychopharmacology. 2008;33:110-33.

17. Brietzke E, Kauer-Sant'Anna M, Teixeira AL, Kapczinski F. Abnormalities in serum chemokine levels in euthymic patients with bipolar disorder. Brain Behav Immun. 2009;23:1079-82.

18. Brietzke E, Stabellini R, Grassi-Oliveira R, Lafer B. Cytokines in bipolar disorder: recent findings, deleterious effects but promise for future therapeutics. CNS Spectr. 2011 Jul 1. pii: Brietzke. [Epub ahead of print].

19. McGorry PD, Hickie IB, Yung AR, Pantelis C, Jackson $\mathrm{HJ}$. Clinical staging of psychiatric disorders: a heuristic framework for choosing earlier, safer and more effective interventions. Aust N Z J Psychiatry. 2006;40:616-22.

20. Berk M, Malhi GS, Hallam K, Gama CS, Dodd S, Andreazza $A C$, et al. Early intervention in bipolar disorders: clinical, biochemical and neuroimaging imperatives. J Affect Disord. 2009; 114:1-13.

21. Berk M. Neuroprogression: pathways to progressive brain changes in bipolar disorder. Int J Neuropsychopharmacol. 2009;12:441-5.

22. Berk M, Kapczinski F, Andreazza AC, Dean OM, Giorlando F, Maes $M$, et al. Pathways underlying neuroprogression in bipolar disorder: focus on inflammation, oxidative stress and neurotrophic factors. Neurosci Biobehav Rev. 2011;35:804-17.
23. Brietzke E, Mansur RB, Soczynska JK, Kapczinski F, Bressan RA, McIntyre RS. Towards a multifactorial approach for prediction of bipolar disorder in at risk populations. J Affect Disord. 2012;140:82-91.

24. Casey DA, Rodriguez M, Northcott C, Vickar G, Shihabuddin L. Schizophrenia: medical illness, mortality, and aging. Int J Psychiatry Med. 2011;41:245-51.

25. Weiner M, Warren L, Fiedorowicz JG. Cardiovascular morbidity and mortality in bipolar disorder. Ann Clin Psychiatry. 2011;23:40-7.

26. Moreira $\mathrm{CL}$, Brietzke $\mathrm{E}$, Lafer $\mathrm{B}$. Comorbidades médicas em pacientes ambulatoriais com transtorno do humor bipolar tipo 1. Rev Psiquiatr Clin. 2011;38:227-30.

27. McIntyre RS, Danilewitz M, Liauw SS, Kemp DE, Nguyen HT, Kahn LS, et al. Bipolar disorder and metabolic syndrome: an international perspective. J Affect Disord. 2010;126:366-87.

28. Mitchell AJ, Vancampfort D, Sweers K, van Winkel R, Yu W, De Hert M. Prevalence of metabolic syndrome and metabolic abnormalities in schizophrenia and related disorders--a systematic review and meta-analysis. 2011 Dec 29. [Epub ahead of print].

29. Thakore JH, Mann JN, Vlahos I, Martin A, Reznek R. Increased visceral fat distribution in drug-naive and drugfree patients with schizophrenia. Int J Obes Relat Metab Disord. 2002;26:137-41.

30. Ryan MC, Collins $P$, Thakore JH. Impaired fasting glucose tolerance in first-episode, drug-naive patients with schizophrenia. Am J Psychiatry. 2003;160:284-9.

31. Maina G, Salvi V, Vitalucci A, D'Ambrosio V, Bogetto F. Prevalence and correlates of overweight in drug-naive patients with bipolar disorder. J Affect Disord. 2008;110:149-55.

32. Kirkpatrick B, Miller BJ, Garcia-Rizo C, Fernandez-Egea E, Bernardo $M$. Is abnormal glucose tolerance in antipsychoticnaive patients with nonaffective psychosis confounded by poor health habits? Schizophr Bull. 2012;38:280-4.

33. Brietzke E, Kapczinski F, Grassi-Oliveira R, Grande I, Vieta E, McIntyre RS. Insulin dysfunction and allostatic load in bipolar disorder. Expert Rev Neurother. 2011;11:1017-28.

34. den Heijer T, Vermeer SE, van Dijk EJ, Prins ND, Koudstaal PJ, Hofman A, et al. Type 2 diabetes and atrophy of medial temporal lobe structures on brain MRI. Diabetologia. 2003;46:1604-10.

35. Raji CA, Ho AJ, Parikshak NN, Becker JT, Lopez OL, Kuller $\mathrm{LH}$, et al. Brain structure and obesity. Hum Brain Mapp. 2010;31:353-64.

36. Gispen WH, Biessels GJ. Cognition and synaptic plasticity in diabetes mellitus. Trends Neurosci. 2000;23:542-9.

37. Attwell D, Laughlin SB. An energy budget for signaling in the grey matter of the brain. J Cereb Blood Flow Metab. $2001 ; 21: 1133-45$.

38. Gjedde A. Blood-barrier glucose transfer. In: Bradbury WB, editor. Physiology and pharmacology of the blood-brain barrier. Berlin: Springer; 1992. p. 65-115.

39. Peters A, Schweiger U, Pellerin L, Hubold C, Oltmanns KM, Conrad $M$, et al. The selfish brain: competition for energy resources. Neurosci Biobehav Rev. 2004;28:143-80.

40. Bosy-Westphal A, Kossel E, Goele K, Later W, Hitze B, Settler $U$, et al. Contribution of individual organ mass loss to weight loss-associated decline in resting energy expenditure. Am J Clin Nutr. 2009;90:993-1001.

41. Hitze B, Hubold C, van Dyken R, Schlichting K, Lehnert H, Entringer $S$, et al. How the selfish brain organizes its supply and demand. Front Neuroenergetics. 2010;2:7. 
42. Madsen PL, Hasselbalch SG, Hagemann LP, Olsen KS, Bulow J, Holm S, et al. Persistent resetting of the cerebral oxygen/ glucose uptake ratio by brain activation: evidence obtained with the Kety-Schmidt technique. J Cereb Blood Flow Metab. 1995; 15:485-91.

43. Schnieder TP, Dwork AJ. Searching for neuropathology: gliosis in schizophrenia. Biol Psychiatry. 2011;69:134-9.

44. Rajkowska G, Miguel-Hidalgo Jj. Gliogenesis and glial pathology in depression. CNS Neurol Disord Drug Targets. 2007;6:219-33.

45. Schroeter ML, Steiner J. Elevated serum levels of the glial marker protein $\mathrm{S} 100 \mathrm{~B}$ are not specific for schizophrenia or mood disorders. Mol Psychiatry. 2009;14:235-7.

46. Zhang $X Y$, Xiu MH, Song $C$, Chen da $C$, Wu GY, Haile CN, et al. Increased serum $\mathrm{S} 100 \mathrm{~B}$ in never-medicated and medicated schizophrenic patients. J Psychiatr Res. 2010;44:1236-40.

47. Andreazza AC, Cassini C, Rosa AR, Leite MC, de Almeida LM, Nardin $P$, et al. Serum S100B and antioxidant enzymes in bipolar patients. J Psychiatr Res. 2007;41:523-9.

48. Uranova N, Orlovskaya D, Vikhreva O, Zimina I, Kolomeets $\mathrm{N}$, Vostrikov $\mathrm{V}$, et al. Electron microscopy of oligodendroglia in severe mental illness. Brain Res Bull. 2001;55:597-610.

49. Cataldo AM, McPhie DL, Lange NT, Punzell S, Elmiligy $S$, Ye NZ, et al. Abnormalities in mitochondrial structure in cells from patients with bipolar disorder. Am J Pathol. 2010;177:575-85.

50. Iwamoto K, Bundo M, Kato T. Altered expression of mitochondria-related genes in postmortem brains of patients with bipolar disorder or schizophrenia, as revealed by large-scale DNA microarray analysis. Hum Mol Genet. 2005; 14:241-53.

51. Clay HB, Sillivan S, Konradi C. Mitochondrial dysfunction and pathology in bipolar disorder and schizophrenia. Int J Dev Neurosci. 2011;29:311-24.

52. Manji H, Kato T, Di Prospero NA, Ness S, Beal MF, Krams M, et al. Impaired mitochondrial function in psychiatric disorders. Nat Rev Neurosci. 2012;13:293-307.

53. Bachmann RF, Wang Y, Yuan P, Zhou R, Li X, Alesci S, et al. Common effects of lithium and valproate on mitochondrial functions: protection against methamphetamine-induced mitochondrial damage. Int $\mathrm{J}$ Neuropsychopharmacol. 2009; 12:805-22.

54. Valvassori SS, Rezin GT, Ferreira CL, Moretti M, Goncalves $\mathrm{CL}$, Cardoso MR, et al. Effects of mood stabilizers on mitochondrial respiratory chain activity in brain of rats treated with d-amphetamine. J Psychiatr Res. 2010;44:903-9.

55. Maurer I, Moller HJ. Inhibition of complex I by neuroleptics in normal human brain cortex parallels the extrapyramidal toxicity of neuroleptics. Mol Cell Biochem. 1997;174:255-9.

56. Sagara $Y$. Induction of reactive oxygen species in neurons by haloperidol. J Neurochem. 1998;71:1002-12.

57. van Nimwegen LJ, Storosum JG, Blumer RM, Allick G, Venema HW, de Haan $\mathrm{L}$, et al. Hepatic insulin resistance in antipsychotic naive schizophrenic patients: stable isotope studies of glucose metabolism. J Clin Endocrinol Metab. 2008;93:572-7.

58. Venkatasubramanian G, Chittiprol S, Neelakantachar N, Naveen MN, Thirthall J, Gangadhar BN, et al. Insulin and insulin-like growth factor-1 abnormalities in antipsychoticnaive schizophrenia. Am J Psychiatry. 2007;164:1557-60.

59. Guest PC, Wang L, Harris LW, Burling K, Levin Y, Ernst A, et al. Increased levels of circulating insulin-related peptides in first-onset, antipsychotic naive schizophrenia patients. Mol Psychiatry. 2010;15:118-9.
60. Sicras A, Rejas J, Navarro R, Serrat J, Blanca M. Metabolic syndrome in bipolar disorder: a cross-sectional assessment of a Health Management Organization database. Bipolar Disord. 2008;10:607-16.

61. Oresic M, Tang J, Seppanen-Laakso T, Mattila I, Saarni SE, Saarni SI, et al. Metabolome in schizophrenia and other psychotic disorders: a general population-based study. Genome Med. 2011;3:19.

62. Verma SK, Subramaniam M, Liew A, Poon LY. Metabolic risk factors in drug-naive patients with first-episode psychosis. J Clin Psychiatry. 2009;70:997-1000.

63. Zamaria N. Alteration of polyunsaturated fatty acid status and metabolism in health and disease. Reprod Nutr Dev. 2004; 44:273-82.

64. Sublette ME, Bosetti F, DeMar JC, Ma K, Bell JM, Fagin-Jones $S$, et al. Plasma free polyunsaturated fatty acid levels are associated with symptom severity in acute mania. Bipolar Disord. 2007; 9:759-65.

65. Bentsen H, Solberg DK, Refsum H, Gran JM, Bohmer T, Torjesen PA, et al. Bimodal distribution of polyunsaturated fatty acids in schizophrenia suggests two endophenotypes of the disorder. Biol Psychiatry. 2011;70:97-105.

66. Ximenes da Silva A, Lavialle F, Gendrot G, Guesnet P, Alessandri JM, Lavialle M. Glucose transport and utilization are altered in the brain of rats deficient in $n-3$ polyunsaturated fatty acids. J Neurochem. 2002;81:1328-37.

67. Bradley AJ, Dinan TG. A systematic review of hypothalamicpituitary-adrenal axis function in schizophrenia: implications for mortality. J Psychopharmacol. 2010;24(4 Suppl):91-118.

68. Vieta E, Martinez-De-Osaba MJ, Colom F, Martinez-Aran A, Benabarre A, Gasto C. Enhanced corticotropin response to corticotropin-releasing hormone as a predictor of mania in euthymic bipolar patients. Psychol Med. 1999;29:971-8.

69. Cervantes P, Gelber S, Kin FN, Nair VN, Schwartz G. Circadian secretion of cortisol in bipolar disorder. J Psychiatry Neurosci. 2001;26:411-6.

70. Schmider J, Lammers CH, Gotthardt U, Dettling M, Holsboer F, Heuser IJ. Combined dexamethasone/corticotropinreleasing hormone test in acute and remitted manic patients, in acute depression, and in normal controls: I. Biol Psychiatry. 1995;38:797-802.

71. Cowansage KK, LeDoux JE, Monfils MH. Brain-derived neurotrophic factor: a dynamic gatekeeper of neural plasticity. Curr Mol Pharmacol. 2010;3:12-29.

72. Neves-Pereira M, Mundo E, Muglia P, King N, Macciardi F, Kennedy JL. The brain-derived neurotrophic factor gene confers susceptibility to bipolar disorder: evidence from a family-based association study. Am J Hum Genet. 2002;71:651-5.

73. Fernandes BS, Gama CS, Cereser KM, Yatham LN, Fries GR, Colpo G, et al. Brain-derived neurotrophic factor as a statemarker of mood episodes in bipolar disorders: a systematic review and meta-regression analysis. J Psychiatr Res. 2011;45:995-1004.

74. Schwartz E, Mobbs CV. Hypothalamic BDNF and obesity: found in translation. Nat Med. 2012;18:496-7.

75. Shugart YY, Chen L, Day IN, Lewis SJ, Timpson NJ, Yuan W, et al. Two British women studies replicated the association between the Val66Met polymorphism in the brain-derived neurotrophic factor (BDNF) and BMI. Eur J Hum Genet. 2009; 17:1050-5.

76. Xu B, Goulding EH, Zang K, Cepoi D, Cone RD, Jones KR, et al. Brain-derived neurotrophic factor regulates energy balance downstream of melanocortin-4 receptor. Nat Neurosci. 2003;6:736-42. 
77. Unger TJ, Calderon GA, Bradley LC, Sena-Esteves M, Rios M. Selective deletion of Bdnf in the ventromedial and dorsomedial hypothalamus of adult mice results in hyperphagic behavior and obesity. J Neurosci. 2007;27:14265-74.

78. Liao GY, An JJ, Gharami K, Waterhouse EG, Vanevski F, Jones $K R$, et al. Dendritically targeted Bdnf mRNA is essential for energy balance and response to leptin. Nat Med. 2012;18:564-71.

79. Chaput JP, Drapeau V, Poirier P, Teasdale N, Tremblay A. Glycemic instability and spontaneous energy intake: association with knowledge-based work. Psychosom Med. 2008;70:797-804.

80. Mitrakou A, Ryan C, Veneman T, Mokan M, Jenssen T, Kiss I, et al. Hierarchy of glycemic thresholds for counterregulatory hormone secretion, symptoms, and cerebral dysfunction. Am J Physiol. 1991;260(1 Pt 1):E67-74.

81. Brietzke E, Mansur RB, Soczynska J, Powell AM, McIntyre RS. A theoretical framework informing research about the role of stress in pathophysiology of bipolar disorder. Prog Neuropsychopharmacol Biol Psychiatry. 2012;39:1-8.

82. Altman S, Haeri S, Cohen LJ, Ten A, Barron E, Galynker, II, et al. Predictors of relapse in bipolar disorder: a review. J Psychiatr Pract. 2006;12:269-82.

83. Moritz S, Burnette P, Sperber S, Kother U, Hagemann-Goebel M, Hartmann $M$, et al. Elucidating the black box from stress to paranoia. Schizophr Bull. 2011;37:1311-7.

84. Shevlin M, Houston JE, Dorahy MJ, Adamson G. Cumulative traumas and psychosis: an analysis of the national comorbidity survey and the British Psychiatric Morbidity Survey. Schizophr Bull. 2008;34:193-9.

85. Horesh N, Iancu I. A comparison of life events in patients with unipolar disorder or bipolar disorder and controls. Compr Psychiatry. 2010;51:157-64.

86. Horesh N, Apter A, Zalsman G. Timing, quantity and quality of stressful life events in childhood and preceding the first episode of bipolar disorder. J Affect Disord. 2011;134:434-7.

87. Thompson KN, Phillips LJ, Komesaroff P, Yuen HP, Wood SJ, Pantelis C, et al. Stress and HPA-axis functioning in young people at ultra high risk for psychosis. J Psychiatr Res. 2007;41:561-9.

88. Kim EY, Miklowitz DJ, Biuckians A, Mullen K. Life stress and the course of early-onset bipolar disorder. J Affect Disord. 2007;99:37-44.
89. van Winkel R, Stefanis NC, Myin-Germeys I. Psychosocial stress and psychosis. A review of the neurobiological mechanisms and the evidence for gene-stress interaction. Schizophr Bull. 2008;34:1095-105.

90. Sterling P. Allostasis: a model of predictive regulation. Physiol Behav. 2012;106:5-15.

91. Sterling $P$, Eyer J. Allostasis: a new paradigm to explain arousal pathology. In: Fisher S, Reason J, editors. Handbook of life stress, cognition and health. New York: John Wiley \& Sons; 1988. p. 629-49.

92. Karatsoreos IN, McEwen BS. Psychobiological allostasis: resistance, resilience and vulnerability. Trends Cogn Sci. 2011;15:576-84.

93. Berk M, Conus P, Kapczinski F, Andreazza AC, Yucel M, Wood SJ, et al. From neuroprogression to neuroprotection: implications for clinical care. Med J Aust. 2010;193(4 Suppl):S36-40.

94. Kapczinski F, Vieta E, Andreazza AC, Frey BN, Gomes FA, Tramontina J, et al. Allostatic load in bipolar disorder: implications for pathophysiology and treatment. Neurosci Biobehav Rev. 2008;32:675-92.

95. Palmer BW, Dawes SE, Heaton RK. What do we know about neuropsychological aspects of schizophrenia? Neuropsychol Rev. 2009;19:365-84.

96. Manove $\mathrm{E}$, Levy B. Cognitive impairment in bipolar disorder: an overview. Postgrad Med. 2010;122:7-16.

97. Gee DG, Cannon TD. Prediction of conversion to psychosis: review and future directions. Rev Bras Psiquiatr. 2011;33 Suppl 2:s129-42.

98. Taylor M, Bressan RA, Pan Neto P, Brietzke E. Early intervention for bipolar disorder: current imperatives, future directions. Rev Bras Psiquiatr. 2011;33:S213-7.

99. Marshall M, Rathbone J. Early intervention for psychosis. Schizophr Bull. 2011;37:1111-4.

100. McGorry PD, Nelson B, Amminger GP, Bechdolf A, Francey $\mathrm{SM}$, Berger $\mathrm{G}$, et al. Intervention in individuals at ultra-high risk for psychosis: a review and future directions. J Clin Psychiatry. 2009;70:1206-12.

\section{Correspondence}

Rodrigo Barbachan Mansur

Rua Pedro de Toledo, 669

04039-032 - São Paulo, SP - Brazil

E-mail: rodrigomansur71@uol.com.br 